Seton Hall University

eRepository@Seton Hall

Department of English Publications

Department of English

$1-1-2014$

\title{
Tidying as We Go: Constructing the Eighteenth Century through Adaptation in Becoming Jane, Gulliver's Travels, and Crusoe
}

Karen Gevirtz

Seton Hall University, gevirtka@shu.edu

Follow this and additional works at: https://scholarship.shu.edu/english-publications

Part of the Cultural History Commons, Literature in English, British Isles Commons, Other Film and Media Studies Commons, and the Television Commons

\section{Recommended Citation}

Gevirtz, Karen, "Tidying as We Go: Constructing the Eighteenth Century through Adaptation in Becoming Jane, Gulliver's Travels, and Crusoe" (2014). Department of English Publications. 33.

https://scholarship.shu.edu/english-publications/33 
Seton Hall University

From the SelectedWorks of Karen Bloom Gevirtz

2014

Tidying as We Go: Constructing the Eighteenth Century through Adaptation in Becoming Jane, Gulliver's Travels, and Crusoe

Karen Gevirtz, Seton Hall University 


\section{PROJECT MUSE}

Tidying as We go: Constructing the Eighteenth Century

through Adaptation in Becoming Jane, Gulliver's Travels, and Crusoe

Karen Gevirtz

Studies in Eighteenth-Century Culture, Volume 43, 2014, pp. 219-237 (Article)

Published by Johns Hopkins University Press

DOI: https://doi.org/10.1353/sec.2014.0003

$\Rightarrow$ For additional information about this article https://muse.jhu.edu/article/543169 


\title{
Tidying as We g o: c onstructing the eighteenth c entury through a daptation in Becoming Jane, Gulliver's Travels, and Crusoe
}

\author{
k a Ren ge ViRTz
}

$\mathrm{W}$

hat exactly does a film adaptation do, and how does it go about doing it? For one set of critics, adaptations offer a retrospective insight into the workings of a source text. ${ }^{1}$ In this view adaptations are dependent or ancillary texts without full meaning in their own right that provide insight retrospectively into an originary text. The adaptation helps an audience to uncover a meaning for, and by extension a relevance of, the source text. ${ }^{2}$ Recently, this approach has essentially given way to an intertextual one that regards an adaptation as a valuable text in its own right, and that sees the relationship between it and its source as dialogic, so that each affects the meaning of the other. ${ }^{3}$ The time is right to complicate this intertextual approach still further by recognizing that the contexts of adaptation and source are also part of the interaction between these works. Texts inevitably interact with their contexts, whether the context of their creation or the context of their consumption or both, and texts have long been used to create or recreate an understanding not just of the present but also of the past. An adaptation can be used to construct an interpretation of a source text, but it can also construct a cultural function for the source in the source's original moment, in the adaptation's moment, or in any moment in between. The three adaptations discussed in this article-Becoming Jane (2007), Gulliver's Travels (2010), and Crusoe (2008-9) - demonstrate how adaptation can function inter-contextually as well as intertextually. Each of these recent 
adaptations constructs a narrative of the Anglo-American past by erasing historical conflicts involving gender, race, and empire, a maneuver with consequences for constructions of the eighteenth century, of history, and of the present.

A key difference between earlier forms of adaptation theory and recent versions is the role that history or context plays in understanding the relationship between the texts. Traditional approaches assume a one-way connection between past and present. In this formulation, the past or the original text has a certain stability against which or with which the adaptation and the present moment can react or engage: there is Daniel Defoe's Robinson Crusoe, for example, and then there are responses to it such as J. M. Coetzee's novel Foe or Derek Walcott's poem "Crusoe's Journal." The intertextual approach on the other hand refuses to privilege chronological order. As Linda Hutcheon says: "One lesson is that to be second is not to be secondary or inferior; likewise, to be first is not to be originary or authoritative." 4 Such an egalitarian relationship has a powerful impact on the understanding and cultural capital of both texts. ${ }^{5}$ Hutcheon points out that adaptations are "haunted at all times by their adapted texts" so that when we know a prior text well, "we always feel its presence shadowing the one we are experiencing directly." Currently, intertextual adaptation theory generally considers this impact in a positive light: Deborah Cartmell and Imelda Whelehan see film adaptations "increasing" or "enhancing" an original text or author's "cultural capital," for example. Critics who are less sanguine about intertextuality express concern about these interactions, particularly about the function of ideology in the relationship between source text and adaptation. Martine Voiret and Sara Maza, for instance, show how adaptations can use source texts and authors to support conservative, even misogynist, classist, and racist ideologies, ideologies that can in turn reduce the quantity or quality of the text or author's cultural capital.?

In addition to the ideological aspects of the connection between source and adaptation, there are the contextual aspects of this connection. An adaptation not only interacts with a source text and with that text's historical context but also with the notion of history itself, an interaction with potentially profound implications. Adaptations influence the present cultural moment through their effect on the interpretation and cultural standing of the source text and, by extension, through a construction of the source text's original cultural moment. The impact on context is particularly evident in a type of adaptation that draws on the eighteenth century as its originary moment. Becoming Jane, Gulliver's Travels, and Crusoe, for example, attempt to use old, perhaps hallowed or sanctified cultural objects to rewrite history and thereby rewrite the current historical moment. Remaking the past in order 
to remake the present betrays a considerable anxiety about that present as well as about history. It also assumes the relevance and the usefulness of the past, assumes the power of the past to shape the present moment, and assumes the cultural value of objects from the past. While the films discussed here may use different strategies for this project, they all invariably use adaptation to construct a narrative about the twenty-first century's origins in the long eighteenth century that encourages a vision of the present moment considerably less conflicted than it would appear in light of historical narratives more willing to include discord, injustice, and error as part of past action and ideology.

As Rachel Brownstein points out in Why Jane Austen?, the last twenty years have seen "an effective dismissal, or at least a high-handed underreading and condescending rewriting, of what [Austen] wrote" as well as an erasure of "Austen's critique of selfishness and greed and a society that measured human worth and human relationships in terms of land and money" through a fascination bordering on an "obsession" with Austen's personal experience of "romance" in its most simplified sense. Crucially, Brownstein notes that our insistence on recasting Austen, and on using these terms to do it, reveals more about our current cultural moment than it does about Austen. ${ }^{8}$ In fact, what Brownstein calls "Jane-o-mania," the explosion of Austen-related material from the 1990s, is part of a larger phenomenon that includes other film responses to works of literature. ${ }^{9}$ Such film responses to "classic" works of literature reveal an anxiety about the past and an eagerness not only to control or limit the relationship between past and present, but also to redefine the past as part of that controlling and limiting effort. They serve to limit through redefinition the relationship between past and present in order to facilitate a vision or version of the current moment. It is revisionism with all that term's connotations in play. Becoming Jane is a case study; together, the films discussed here mark a trend.

Austen's conversion from a "great author" to a fortunately jilted woman is a key symptom of this enterprise. Recent film responses to Austen and her work, primarily The Real Jane Austen (2002), Becoming Jane (2007), Miss Austen Regrets (2008), The Jane Austen Trilogy (2010), and Gillian Anderson's introductions to the Austen series on PBS in 2008, draw a direct connection between certain aspects of Austen's personal history, some more speculative than others, and her novels in order to provide both an interpretation of the work and an explanation for the fact of Austen writing. ${ }^{10}$ Anderson's statements that "Jane Austen is obviously making up for what's missing in her own life and putting it in her fiction" or "Who taught Jane Austen to recognize and understand these feelings? Was it a young man called Tom Lefroy?" or the trailer for Becoming Jane that invites viewers to 
"Discover Jane Austen's untold romance, that would become the inspiration for her greatest love stories," insist on reading the fiction as encoded autobiography. ${ }^{11}$ This approach is an extension of Jon Spence's thesis in Becoming Jane Austen that if Austen's relationship with Lefroy continued as late as 1796, then readers must conclude that the disappointment shaped her writerly choices until nearly the end of her life, thirty years later. ${ }^{12}$ Becoming Jane therefore is ostensibly a film adaptation of the speculative narrative that Spence crafts based on the 1796 letter. As Spence points out, however, while his biography may have provided a hypothesis, the screenwriters provided what is presented as biography or history: "The scriptwriters of Becoming Jane have imagined what might have happened during this time," he writes, adding that "the plot and incidents of the film are fictional." This claim differs from that made by the film's publicity, which declares that "Jane Austen's Most Extraordinary Romance Was Her Own."13

While feminist critics from the 1980s pioneered the use of biography as literary criticism, the insistence on using only the life of the author to explain the meaning and existence of the author's productions in this form limits the opportunity for reading the work as socio-political critique or viewing the author as a critical force. ${ }^{14}$ Tom Lefroy's assertion in Becoming Jane that "your horizons must be-widened. By an extraordinary young man" in order for Jane Austen to become a great writer is the primary claim of the film: that Austen has been introduced to ideas and to experience by a man, that he has "author-ized" and "authored" the author, as it were. ${ }^{15}$ Martha Nell Smith points out that contemporary culture has a "limited range of story lines for scripting poetic influence and erotic devotions." The use of any of these storylines to script a life that does not actually fit them, she argues, has profound implications for the understanding of that author's work, and for the construction of that author as a literary and cultural presence. ${ }^{16} \mathrm{In}$ particular, the "near-hegemonic prevalence of conscriptive heterosexual story lines render inscrutable" literary practices outside this narrative formula, as the determined inscription of Austen's life within the bounds of familiar, conventional, and subjugating romance attests. ${ }^{17}$

In rewriting Austen's personal history, the film shapes current literary culture. With her artistry the result of a male gift, Austen's place in the canon changes, arguably diminishes, and so do the positions of other women writers who now may be judged on how their lives, rather than their skills, shaped their work. It is hardly a phenomenon limited to Austen; as Madeleine Dobie points out: "The problem of the recent Austen adaptations in this regard may perhaps be seen as a reflection of the continuing problem of women writers' place in the literary canon. Austen has long been accepted as a key figure in the history of English literature, yet like many other women writers, she 
occupies within this circle of prestige a circumscribed, distinctly feminine position, which at worst amounts to qualified acceptance, or to recognition as a woman writer." ${ }^{18}$ This phenomenon can be understood as part of a larger trend of "screening the author"- using a film to present the author behind the source material. ${ }^{19}$ This interest in attributing Shakespeare's work to his life experience produced Shakespeare in Love (1998), for example, and the Bard has recently come under renewed scrutiny in the film Anonymous (2011). Becoming Jane Austen has inspired the title of Robert Douglas-Fairhurst's biography, Becoming Dickens (2011).

There are important differences within this trend, however: "screening the author" does not occur the same way for all authors nor are the consequences the same. Shakespeare's ill-starred love affair with Viola de Lesseps in Shakespeare in Love did not make him a playwright; the film opens when he is established in that career. Furthermore, while the affair with her may have helped break his writer's block, Viola herself did not. As for Anonymous, few viewers, film critics, or scholars took it all that seriously, although The Shakespeare Birthplace Trust did organize a protest throughout Warwickshire..$^{20}$ The press called the film "revisionist," an adjective with disreputable connotations but not one applied to any of the so-called "biopics" of Jane Austen. In contrast, when Kathryn Sutherland attributed Austen's writing style to Austen's editor, she provoked a storm of discussion. Significantly, the defense of Austen received much less attention than Sutherland's initial claim. ${ }^{21}$ Spence's Becoming Jane Austen is subtitled "A Life," while Douglas-Fairhurst's Becoming Dickens is subtitled "The Invention of a Novelist." This difference in title indicates a difference in approach: Jane Austen becomes a person, whereas Charles Dickens was already a person but becomes a professional writer. In the same vein, the title of Spence's biography uses Austen's full name but Douglas-Fairhurst's uses only the last: referring to someone by their last name is generally a mark of respect and distance - think, "Are you trying to seduce me, Mrs. Robinson?"- and in literary circles, an author is identified by the last name, not the first. Furthermore, Spence's title is shortened to Becoming Jane for the film version, establishing an intimacy between audience and subject that the title Becoming Dickens cannot. This intimacy appears in other materials taking a biographical approach to Austen and her work, such as Sundays with Jane, the supplemental website PBS launched to accompany their Austen film series in $2008 .^{22}$ The fact is that "screening the author" for Austen changes her cultural capital, with implications for Austen's place in the canon. As Smith observes, "Stories of romantic thralldom with men or of relationships with a male mentor are proliferatively familiar." ${ }^{, 23}$ Alternative life narratives are not. When Austen's personal history is rewritten to fit a "proliferatively 
familiar" narrative, literary history is rewritten as well; in this case, revised to remove the phenomenon of a woman who was not contained within the usual constructions of femininity-unmarried yet unforlorn, keenly and clearsightedly critical of not just people, but institutions and systems around her.

While the consequences of these maneuvers are significant and symptomatic of a familiar effort to reduce or negate women's contributions to the public sphere, ${ }^{24}$ they also constitute one aspect of a larger project to cleanse the past of conflict and challenge, and thereby justify aspects of the historical present. Further examples of how adaptations can serve this purpose are the 2010 film version of Gulliver's Travels starring Jack Black and Crusoe, a television series from 2008-2009. ${ }^{25}$ In the hands of screenwriters Joe Stillman and Nicholas Stoller, Jonathan Swift's satire becomes the story of Lemuel Gulliver, the mailroom clerk at a large New York newspaper who lies to the travel editor, Darcy Silverman, about being a travel writer, gets an assignment to the Bermuda Triangle and winds up on Lilliput. There he defeats the Blefuscians, as they are called in the film, becomes the hero of Lilliput, is eventually unmasked as a fraud when he allows Lilliput to fall to Blefuscu, and is exiled to Brobingnag. Rescued by his Lilliputian friend Horatio, Gulliver liberates the Lilliputians, ends the war, and returns to New York to assume a career at the newspaper as a travel writer and as the boyfriend of Darcy Silverman, who he also has rescued after she followed him to the Bermuda Triangle and was captured in Lilliput by Blefuscian troops. ${ }^{26}$

In Stillman and Stoller's Gulliver's Travels, the past and its narratives must be rejected. This adaptation argues that history can have a direct and restricting influence on the present, and should therefore be treated with skepticism if not outright dismissal. The film makes this point in part by simplifying and homogenizing history. ${ }^{27}$ Lilliput becomes "the past" in material form, but "the past" is invoked by conventional symbols such as speeches in which every word ends in -eth, eighteenth-century English architecture, Dickensian children in the street, and even the villainous general's full name, Edward Edwardian. The Blefuscians use nineteenthcentury diving gear, sail ships from Golden Age Spain, and wear uniforms from Bismarck's Germany. As Dianne F. Sadoff and John Kucich note about a different film adaptation, Amy Heckerling's Clueless (1995), the film "flaunts a manic historical insouciance." ${ }^{28}$ Lilliput becomes a museum, and as in a museum, as Umberto Eco or Susan Stewart would point out, by displaying objects from different periods all together, Lilliput collapses time and space into one display; in collections, Stewart notes, "all time is made simultaneous or synchronous within the collection's world." ${ }^{29}$ None 
of it has independent meaning, and the collection as a whole is by definition "a fake," in Eco's words. ${ }^{30}$

A more sinister view of the past is expressed through the character of General Edward. His slavish adherence to restrictive Lilliputian traditions embodies the danger of tradition and the threat that the past poses to the potential of the new. Violence makes him happy—he excuses himself from Princess Mary's company with a cheerful "Must go. Those villages won't pillage themselves" - and he is overtly misogynist. He announces, "I can't be expected to take orders from a gargantuan fool. I would rather take orders from a woman," tells the Princess that he wants to marry her because of her breasts, interrupts her tender memories of her grandmother with stories about himself, and repeatedly and sinisterly invades her bedroom uninvited. (Twenty-first-century American male Gulliver, however, has no difficulty accepting a woman in authority: the film concludes with his reporting to Darcy upon his return from an assignment). The happy ending for Lilliput requires General Edward's literal overthrow, first by the team of Gulliver and Horatio, and then by Princess Mary, who coldcocks him when he attempts to kidnap her. ${ }^{31}$ For this adaptation, history is a foreign country with a tendency to violence and misogyny.

History is also comprised of what General Edward calls "silly, silly, silly stories." Gulliver uses such stories to invent himself, once when he tells Darcy Silverman that he travels and writes travel pieces, the other when he invents himself as "President the Awesome" of Manhattan for the Lilliputians. In both instances, Gulliver fabricates a present identity by constructing a past out of others' narratives, whether plagiarized from travel websites or from blockbuster films including Titanic (tellingly, he does not use history but James Cameron's film fiction about the event), the Star Wars series, X-Men, Avatar, Pirates of the Caribbean, and 24. His improbable and badly-written amalgam is indeed "silly, silly, silly." Unlike Swift's narrative, which draws on different contemporary genres both to establish itself and often to satirize them, the film rejects the use of stories by making fiction the key to Gulliver's failure. Once he stops constructing himself out of narratives, particularly narratives from and about the past, he is permitted to succeed, and the future he succeeds to is certainly rosy: he is a respected authority on transient experience, i.e., a travel writer, and he is romantically involved with Darcy.

Given this attitude toward history and especially narratives from the past, it is not surprising that the film would have an ambivalent attitude toward its own identity as an adaptation, a narrative depending on a text from the past for its existence. The film mildly acknowledges cinematic predecessors in its borrowing of certain conventions, such as Gulliver's love interest 
(originally appearing in The Three Worlds of Gulliver [1960] and the 1996 Gulliver's Travels) and a pair of star-crossed Lilliputian lovers (introduced in Max and Dave Fleischer's 1939 animated Gulliver's Travels and recycled in The Three Worlds of Gulliver). The film's handling of "classic" literature is less ambiguous, if only because it is more overt. For Stillman and Stoller, such texts undeservedly occupy sacred cultural space thanks to the uncritical acceptance of "readers" like the Lilliputians..$^{32}$ But it is not just uncritical acceptance that is a problem, according to Stillman and Stoller: the original texts are equally undeserving. They revise Cyrano de Bergerac's famous ventriloquism scene, for example, so the Lilliputian Horatio, prompted by Gulliver crouched behind the palace, woos Princess Mary with the lyrics to Prince's Kiss as she stands on a balcony. Edmond Rostand's original scene is poignant and sharply critical. Stillman and Stoller's scene is shallow, comic, and conventionally romantic.

This conversion of satire and criticism into romance is the key tactic for the film's rejection of the past on one hand, and its sanitizing it on the other. Swift's narrative brilliantly and brutally exposes the problems of the socio-economic and political forces of its day, including the pettiness and corruption of the English government, the barbarity of war, and the cruel exploitation of the agricultural and imperialist systems. Stillman and Stoller instead use the cover of the older narrative to promote the corporate values that have origins in the institutions and systems that Swift attacked. Although like Swift's Gulliver's Travels, Stillman and Stoller's Gulliver's Travels critiques war, for example, their film uses a Hollywood-musical scene of Lilliputians and Blefuscians, led by Gulliver, singing and dancing to "War! (What is it good for?)" In converting satire into comedy, the film diffuses critique. Similarly, Times Square becomes a touchstone of a positive present, portrayed with a lively, upbeat soundtrack in the opening credits. This location marks the apogee of success for Gulliver. When he is at the height of his popularity in Lilliput, he remakes the capital into Times Square and hosts a public music festival there (with the aid of his iPod, which also gets screentime), thus converting one of the most famous sites of western capitalism into a locus of altruism. Gulliver's triumphant ending is a literal return to Times Square and corporate work. Furthermore, his boss is a woman, suggesting that there is no glass ceiling here, at least not if you are a beautiful, single woman who needs rescuing by your male subordinates. Gulliver's Travels thus is adapted to affirm limited contemporary values: success means becoming a corporate cog; war is bad (but individuals fighting each other is good entertainment); women in authority are acceptable (as long as they are also sexy and use their authority to elevate men) $;^{33}$ and so forth. Pretending to tell Swift's story, Stillman and Stoller really tell contemporary 
western capitalism's favorite narratives about "reinventing the individual" and "corporate life is the ultimate in happiness," sanitizing history of the violence, heartlessness, and exploitation targeted by Swift. Without a past to connect the present to, whatever narratives are in circulation to explain the present face considerably less challenge.

At first glance, Stillman and Stoller's cleansing and rejection of the past seems opposite to the approach taken by the television series Crusoe that ran on NBC in the United States during 2008-2009. For Crusoe's writers, history's influence is inescapable and necessary. Through the frequent use of flashbacks, the series emphasizes the importance of Robinson's personal history as well as his place in actual history. Scenes like these explain how Robinson got to this point by defining Dissenters, or showing Robinson unwittingly aiding soldiers fighting for Monmouth and being tried for treason by Judge Jeffries. Here, history is considered very relevant for the present. Because of this influence, however, it becomes imperative for the health of the present that the past be remade. Crusoe uses the premise of the original narrative - in this case, a determined, resourceful man stranded on an island with a companion named Friday who wants to escape this isolation - to present a highly heterosexualized, anti-imperialist, racially-harmonized, technophilic vision not just of the past, but also of the present in which the show was viewed. ${ }^{34}$

The homosocial and homosexual underpinnings of Defoe's original narrative have been well-explored elsewhere. ${ }^{35}$ The writers for the television series have assiduously attempted to erase any traces of queerness, however. Their Robinson is determinedly heterosexual, which they reinforce with flashbacks of his sexual relationship with Suzanna and a collection of nubile young women who are attracted to him; Friday calls it "the Crusoe effect." But Crusoe is also virtuous and thoroughly housebroken: he resists all the women by averring his fidelity to and love for his wife, and with frequent articulations of his desire to return to her and their two children. One subplot of episode two, "Sacrifice," involves the loss of Robinson's wedding ring, which he is desperate to retrieve and finally does, to the romantic strains of a harp and oboe on the soundtrack. Friday, for his part, has family issues of his own, with a recurring subplot about tensions with his father. He, too, is resolutely heterosexual, being the recipient of a warrior princess's attentions in episode ten, "The Hunting Party." Friday and Robinson also call each other "brother," using a sibling vocabulary to further diffuse the possibility of queerness. In episode eight, "Name of the Game," the two men repeatedly discuss what they learned from their fathers and the ways in which they fear that they have let down those fathers. Friday and Robinson live in comfortable domesticity on their deserted island, far removed from 
either man's civilization; episodes repeatedly open or close, and sometimes do both, with a scene of cooking and sharing food at their treehouse. Nevertheless, each man is seeking emotionally and physically to leave this home for heterosexual family life.

DeeAnn DeLuna has complicated some of the most overt of the queer readings of Defoe's novel to argue that "Crusoe's sexual identity is aligned with the novel's focus on his mercantile exertions and their Christianization by Defoe, but in a way which bears no logic of correspondence with an alleged representation of homosexual desire." ${ }^{" 36}$ Similarly, the writers for the series Crusoe have used his domestic heterosexuality to cleanse Robinson's commercial ambitions. Like Defoe's, their Crusoe wants to make money, but unlike Defoe's, their Crusoe does so in order to support his family. Throughout the episodes, flashbacks show how Robinson has been driven to colonialism by social, political, and economic oppression in England, which prevented him from providing for his beloved wife and children. In "The Name of the Game," a flashback reveals that Robinson exchanged a profitable coffee plantation for passage to England on the next tide when he learned that his family is in danger. Laura Brown argues that women often served to justify British imperialism: in order to provide for the little woman at home, countries must be conquered and elephants killed. Certainly, Brown notes, Defoe justified imperialism on this count. ${ }^{37}$ Television's Crusoe performs the same maneuver, legitimating Robinson's mercantilism as a means of supporting his wife and children. Robinson's desire to return to his family converts the "solitary man" narrative central to Defoe's work as well as its associations with wealth for wealth's sake into a social, romantic, selfless, and heterosexual narrative thoroughly familiar and palatable to television viewers. Hence, his domestic heterosexuality is not only used to avoid even the notion of homosexuality, but also to legitimate British imperialism and with it, the global capitalism that ultimately arose from these beginnings.

Other fraught elements of the Anglo-American present are cleaned up and justified by Crusoe, as well. Crusoe and Friday's brotherhood rewrites the history of race in the Americas just as it rewrites the relationship those characters experience in Defoe's Robinson Crusoe. The racial element of Defoe's Robinson Crusoe has proved uncomfortable for filmmakers for the last few decades, so there is nothing new in Crusoe's handling of this element of the original. ${ }^{38} \mathrm{At}$ least there is a Friday at all; as Robert Mayer points out, in Cast Away (2000), the human, dark-skinned, independent Friday becomes a volleyball called "Wilson" by the Crusoe character (named Chuck Noland, played by Tom Hanks). ${ }^{39}$ Although in the television series, Robinson does liberate Friday from cannibals, Friday immediately becomes his partner, his "brother." They share household chores and nurture each other by cooking, 
caring for pets and livestock, and nursing each other through sickness and injury. ${ }^{40}$ In episode five, "Long Pig," Robinson tells Friday that they are safe from cannibals because "We have traps near the beach and a home we can defend," using the key image of the defended home to confirm both the domesticity and the first-person plural of their situation.

The two men also share a rivalry of equals. Unlike in the novel, Friday acquires impeccable English, which he adds to the roster of languages he already speaks; develops a taste for Milton's sonnets; and memorizes Paradise Lost. Robinson, on the other hand, never learns to pronounce Friday's language, as he admits early in the pilot episode. In addition, a current of competition runs through the series. Although Robinson consistently supplies the engineering and scientific knowledge and skill, the episode "Name of the Game" is based on Friday's efforts to match Robinson's feats. On the other hand, Friday repeatedly bests Robinson in feats of physical skill. The men roughhouse and "play games," as Robinson calls them in the episode "Bad Blood," attacking each other with weapons and fighting both to compete and to keep themselves ready for the inevitable attack by outsiders. In the pilot episode, Friday rescues Robinson from pirates who are pursuing him through the jungle:

Friday: Friday wonders what kind of idiot builds all those
traps, then runs yelling to the beach without a weapon.
Crusoe: You knew I was at the beach?
Friday: I could guess it, from the beacons.
Crusoe: Well, in that case, Crusoe wonders, why Friday didn't
join in sooner?
Friday: I was enjoying the Idiot Show.

In the concluding episode of the series, Friday shoots arrows to frighten off rather than kill sailors trying to kill them, because Robinson wishes those sailors to summon their superiors. "It offends me to miss deliberately," Friday says waspishly to Robinson, and Robinson apologizes for asking it of him. In scenes like this one, the imbalance between Defoe's Friday and Crusoe is not only adjusted, but tipped in the other direction: Robinson does not command Friday's help but asks it, which means that he depends upon Friday and owes him gratitude, an inferiority of position thoroughly unfamiliar to Defoe's Crusoe. As scholars have pointed out, Defoe's narrative is deeply implicated not just in imperialism and colonialism, but specifically in the slave trade and the racism that was developed to sustain and justify it. ${ }^{41}$ Interaction between the races in the seventeenth-century Americas is thus reconstructed to provide a fluidity of power dynamics, a respect, and 
a mutuality that actual history does not generally indicate. It is an ideal of the past and an ideal of the present, not unlike the claims following the election of Barack Obama in 2008 that the United States is a "post-race" society. ${ }^{42}$ According to Crusoe, virtuous people yearn for and actively seek a brotherhood of men, hence the presumed audience satisfaction when it appears on the small screen.

While Crusoe idealizes heterosexual norms and justifies capitalism expressed through domesticity and racial equality, its most overt object of adoration is technology. In Defoe's narrative, Crusoe struggles with the basics of subsistence, as he already lives in a world where the consumer does not produce his own goods. In Robinson Crusoe, Crusoe is delighted to make raisins by accident, struggles to discover how to make bread, and learns the hard way how to build a sheep pen and a canoe. These are not technologically advanced objects; perhaps the most complicated undertaking is his umbrella, which takes him years to accomplish. In Crusoe, however, Robinson, and Friday to a more limited extent, are brilliant engineers. Food, clothing? The boxes washed up from Robinson's shipwreck and their own ingenuity with indigenous materials suffice. In the pilot episode, deprived of their gunpowder, Friday improvises a weapon by dismantling an umbrella (surely no accidental reference to the original novel) while Robinson makes throwing stars from coins. In other episodes Robinson forges a skeleton key, a compass, a telescope, and a tranquilizer dart. Defoe's Crusoe lives in a cave. Robinson and Friday occupy a multileveled tree house not only balanced through the canopy of several trees and cantilevered over the edge of a cliff, but also complete with wind power, running water, and a juicer. Crusoe has two walls of spiky poles and a ladder to get over them. Robinson and Friday have a ladder bridge over a bottomless swamp, a giant wheel in which they walk like bipedal hamsters to cross a chasm and when that is destroyed, a rope bridge over it. From the base of the main tree, they ascend to their house by elevator. Robinson "becomes a seventeenth-century MacGyver," says one of the program's art directors proudly. ${ }^{43}$

Their technological ingenuity is emphasized in the visual vocabulary and emphasis of the series, such as lingering camera shots of their work and the recurring image of the airy tree house as the visual shorthand of their domestic base. Director Duane Clark states, "The fact [is] that the whole show opens up with this rather clever device that he has: this spyglass that he's fashioned out of some lenses and some brass salvaged from the ship." 44 As Robinson puts it succinctly in episode four, "High Water," "What's the point of making tools if it doesn't make the job easier?" Villains, on the other hand, are marked by their scientific ignorance or crudeness. Pirates have a map etched into the skin on the back of a prisoner. A mutinous ship's 
doctor cannot tell one medicine from another. In the final episode, Robinson's antagonists steadily destroy Robinson and Friday's technological marvels and repeatedly struggle to comprehend the principles underlying those marvels. At the end, Robinson's superior knowledge of science and medicine, like his superior grasp of engineering and physics, enables him to recognize the signs of plague on the captain of the British ship. While his leaping off the ship with Friday seems inexplicable and practically suicidal to the villains on board, the final moments of the series show another plague-infested mariner exiting his prison to infect the rest of the ship. Crusoe thus converts Defoe's recognition of the alienation of seventeenth-century people from the basics of survival into a technophilic past, one that looks familiar and that justifies a technophilic present. ${ }^{45}$

Recently, Raymond Malewitz has argued that behaviors like Friday and Robinson's belong to "new archetypes in contemporary American culturerugged consumers" who "repurpose[...] the objects in their environments" and "ennoble such actions by viewing them through the intertwined American myths of primal nature and rugged individualism." ${ }^{\prime 46}$ Although Malewitz invites "others to determine" whether "such behaviors subvert or in fact support the conditions of late capitalism," he inadvertently answers the question, at least in part, by noting that the "literary imagination" in such moments is "reflecting the current repurposing culture but also asking us to reimagine the creative relations between humans and all objects that populate our worlds. ${ }^{~} 47$ Behaviors like repurposing may affect the relationship between human and object, that is, but they do not in and of themselves necessarily change the system within which that relationship is constituted and conducted. Friday and Robinson repeatedly repurpose what they find in order to resist the commodification of Friday by intruders on the island, who inevitably wish to kill Robinson and sell Friday, but they do not ultimately resist capitalism any more than Gulliver does in Stillman and Stoller's film.

In his review of Stillman and Stoller's Gulliver's Travels for The New York Times, A. O. Scott, taking the persona of Swift, writes, "Surely I state what can only be apparent to any man not a Jackass when I observe that it bears little relation to my original Work. Perhaps you construe that my intent in this epistle is to thunder against a grievous misappropriation of my Book, but please be assured that I have no such complaint. An Apple is but an Apple, while an Orange is some other thing." ${ }^{48}$ Classifications of fruit notwithstanding, Scott is missing a central issue to Gulliver's Travels and the other films discussed here, which is that as Hutcheon points out, an adaptation cannot by its nature be "some other thing" entirely: "We experience adaptations (as adaptations) as palimpsests through our memory of other works that resonate through repetition with variation," as 
she explains. ${ }^{49}$ But as these adaptations suggest, the palimpsest itself can change if the adaptation works to revise the construction of that source's original moment.

Why should this be news to us? Shakespeare attempted such a maneuver with his history plays, after all. Mary Favret notes that the Victorians undertook a similar project with Austen, even if they were more interested with containing her through domesticity than through romance. ${ }^{50}$ When we seek to understand adaptations as adaptations, and not as separate or "standalone" texts - and that certainly can be done, as literary history testifies on numerous occasions - then we ought to consider how the relationship between contexts is inter-contextual, just as the relationship between adaptation and source is intertextual. Inter-contextuality is unlikely to be the same for all relationships, any more than the relationship between texts is always the same, but as adaptation studies continues to flourish, we might now begin to consider other pieces in the puzzle. Furthermore, the role of ideology in the construction of source, adaptation, and context makes the function of adaptation in any given historical moment particularly significant. Eco points out that the Middle Ages "have always been messed up in order to meet the vital requirements of different periods," and he describes "at least ten types of Middle Ages, to warn readers that every time one speaks of a dream of the Middle Ages, one should first ask which Middle Ages one is dreaming of." ${ }^{51}$ In changing the nature of the value of historical products, our own moment changes profoundly and the possibilities and powers of that moment change, as well. The very real relationship between the source and adaptation has, in turn, very real ideological consequences here and now. For Eco, the answer to this question - "what kind of Middle Ages are we talking about" - reveals if, in his words, "we are supporting, perhaps without realizing it, some new reactionary plot." ${ }^{52}$ We should examine what long eighteenth century we are dreaming of with such adaptations, and with it, what present we are dreaming, as well. 


\section{N O T E S}

The author would like to acknowledge the support of Angela Weisl, Donovan Sherman, Jonathan Farina, and Aleksondra Hultquist in writing this article.

1. The term "adaptation" is often used to refer to any text based on a textual forebear; as Linda Hutcheon defines them, "adaptations have an overt and defining relationship to prior texts." In this sense, film versions of Gulliver's Travels and Sense and Sensibility are adaptations in the way that Foe and Clueless are adaptations. "Adaptation" is often used as a catch-all phrase for works with different relationships to originals: Becoming Jane, for example, is not an adaptation of Jon Spence's Becoming Jane Austen in the same way that the 1995 A\&E/BBC production of Pride and Prejudice is an adaptation of Austen's novel, but it is an adaptation of the story that Spence hypothesizes. In this article, "adaptation" refers to a text that claims to be a transposition of an original in one medium into another medium, such as the film Gulliver's Travels and television series Crusoe discussed here. Linda Hutcheon, A Theory of Adaptation (New York: Routledge, 2006), 7; Jon Spence, Becoming Jane Austen: A Life (London: Hambledon Continuum, 2003).

2. Writing about contemporary Robinsonades, for example, Charles W. Pollard concludes, "[T] eaching these contemporary works helps students see how Crusoe's world is still a place that they have both lived in and come out of, a place that remains useful because it helps them understand themselves by understanding their past." See his "Teaching Contemporary Responses to Robinson Crusoe: Coetzee, Walcott, and Others in a World Literature Survey," in Approaches to Teaching Defoe's Robinson Crusoe, ed. Maximillian E. Novak and Carl Fisher (New York: The Modern Language Association, 2005), 168.

3. See for example Hutcheon, Adaptation; Imelda Whelehan, "Adaptations: The Contemporary Dilemmas," in Adaptations: From Text to Screen, from Screen to Text, ed. Deborah Cartmell and Imelda Whelehan (New York: Routledge, 1999), 3-19; Brian McFarlane, "Reading Film and Literature," in The Cambridge Companion to Literature on Screen, ed. Deborah Cartmell and Imelda Whelehan (Cambridge: Cambridge University Press, 2007), 15-28; Deborah Cartmell and Imelda Whelehan, "Introduction-Literature on Screen: A Synoptic View," in Cartmell and Whelehan, Cambridge Companion, 1-12; Thomas M. Leitch, "Literature vs. Literacy: Two Futures for Adaptation Studies," in The Literature/Film Reader: Issues of Adaptation, ed. James M. Welsh and Peter Lev (Lanham, MD: Scarecrow Press, 2007), 15-34; Gina Macdonald and Andrew Macdonald, Introduction to Jane Austen on Screen, ed. Gina Macdonald and Andrew Macdonald (Cambridge: Cambridge University Press, 2003), 1-8.

4. Hutcheon, Adaptation, xiii.

5. The popular use of "cultural capital" often equates the term with "cultural cachet," but Pierre Bourdieu formulated "cultural capital" as the fusion of a linguistic value and a social value that is signaled by how a text is treated by systems and institutions of dissemination and propagation, such as the university and print culture. It is not simply a matter of "how much" cultural capital a text possesses 
or is assigned, but "what kind" of cultural capital: as John Guillory puts it, "the canonical form in its social and institutional contexts." Pierre Bourdieu, Distinction: A Social Critique of the Judgement of Taste, trans. Richard Nice (Cambridge, MA: Harvard University Press, 1984); John Guillory, Cultural Capital: The Problem of Literary Canon Formation (Chicago: The University of Chicago Press, 1993), ix, xiii, original emphasis.

6. Hutcheon, Adaptation, 6.

7. Cartmell and Whelehan, "Introduction," 6; Martine Voiret, "Books to Movies: Gender and Desire in Jane Austen's Adaptations," in Pucci and Thompson, Jane Austen and Co., 229-45; Sarah Maza, "It Can't Go on Like This': Dangerous Liaisons in the Reagan-Thatcher Years," in Jane Austen and Co.: Remaking the Past in Contemporary Culture, ed. Suzanna R. Pucci and James Thompson (Albany: SUNY Press, 2003), 93-110. See also Walter C. Metz, "The Cold War's 'Undigested Apple-Dumpling': Imaging Moby-Dick in 1956 and 2001," in Welsh and Lev, Literature/Film Reader, 65-76; Jessica Durgan, "Framing Heritage: The Role of Cinematography in Pride \& Prejudice," Persuasions On-Line 27, no. 2 (Summer 2007): np., http://www.jasna.org/persuasions/on-line/vol27no2/durgan.htm; Ruth Perry, "Sleeping with Mr. Collins," in Pucci and Thompson, Jane Austen and Co., 213-28; Joyce Goggin, "Pride and Prejudice Reloaded: Navigating the Space of Pemberley,” Persuasions On-Line 27, no. 2 (Summer 2007): np., http://www.jasna. org/persuasions/on-line/vol27no2/goggin.htm; Madeleine Dobie, "Gender and the Heritage Culture: Popular Feminism Turns to History,” in Pucci and Thompson, Jane Austen and Co., 247-59. See also Linda Troost and Sayre Greenfield, eds. Jane Austen in Hollywood, 2nd ed. (Lexington: University Press of Kentucky, 2001).

8. Brownstein, Why Jane Austen? (New York: Columbia University Press, 2011), 4, 7, 247. Mary Favret points out that the Victorians undertook a similar project with Austen, constructing Jane Austen to fulfill wishful thinking about their own cultural moment and to satisfy a nostalgia for a lost, better past. Mary Favret, "Being True to Jane Austen," in Victorian Afterlife: Postmodern Culture Rewrites the Nineteenth Century, ed. John Kucich and Dianne F. Sadoff(Minneapolis: University of Minnesota Press, 2000), 66.

9. Brownstein, Why Jane Austen?, 6. See also Suzanne R. Pucci and James Thompson, "Introduction: The Jane Austen Phenomenon: Remaking the Past at the Millennium," in Pucci and Thompson, Jane Austen and Co., 1; John Kucich and Dianne F. Sadoff, eds. Victorian Afterlife.

10. Brownstein, Why Jane Austen?; Karen B. Gevirtz, “(De)Constructing Jane: Converting 'Austen' in Film Adaptations,” Persuasions On-Line 31, no. 1 (December 2010): np., http:/www.jasna.org/persuasions/on-line/vol31no1/gevirtz.html.

11. "Introduction to Mansfield Park," from a performance televised by PBS on January 27, 2008; "Introduction to Sense and Sensibility, part 1," from a performance televised by PBS on February 1, 2008; "Becoming Jane," Miramax, 2007, http:// www.imdb.com/title/tt0416508/.

12. Spence, Becoming Jane Austen.

13. Spence, Becoming Jane Austen, ix; advertisement for Becoming Jane, Miramax, 2007. 
14. Brownstein, Why Jane Austen?, 7.

15. Becoming Jane, directed by Julian Jerrold (Santa Monica, CA: Miramax Films, 2007), DVD.

16. Martha Nell Smith, "Suppressing the Books of Susan in Emily Dickinson," in Epistolary Histories, ed. Amanda Gilroy and W. M. Verhoeven (Charlottesville: University Press of Virginia, 2000), 101, 104.

17. Smith, "Books of Susan," 104.

18. Dobie, "Gender and the Heritage Culture," 257.

19. Cartmell and Whelehan, "Introduction," 8.

20. Donovan Sherman, "Stages of Revision: Textuality, Performance, and History in Anonymous," Literature/Film Quarterly 41, no. 2 (2013) (forthcoming). The author thanks Dr. Sherman for sharing his analysis in advance of publication. A. O. Scott writes, “'Anonymous,' a costume spectacle directed by Roland Emmerich, from a script by John Orloff, is a vulgar prank on the English literary tradition, a travesty of British history and a brutal insult to the human imagination. Apart from that, it's not bad." A. O. Scott, "How Could a Commoner Write Such Great Plays?" The New York Times, October 27, 2011, http://movies.nytimes.com/2011/10/28/ movies/ anonymous-by-roland-emmerichreview. html. For a report of The Shakespeare Birthplace Trust's response, see Ben Child, "Shakespeare film Anonymous has lost plot, says Stratford," The Guardian, October 25, 2011, http://www.guardian.co.uk/ film/2011/oct/25/shakespeare-filmanonymous-stratford.

21. For a comprehensive summary of the reaction to Sutherland's claims and a practical refutation of them, see Geoff Nunberg, "Was Jane Austen Edited? Does It Matter?" Fresh Air, November 17, 2010, NPR.org, http://www.npr. org/2010/11/15/131335890/was-jane-austen-edited-does-it-matter.

22. This website is no longer available.

23. Smith, "Books of Susan," 102.

24. For further discussion of how recent adaptations constitute a backlash against women, see for example Dobie, 247-59; and Voiret, 229-45.

25. For a more detailed examination of the relationship between Jonathan Swift's Gulliver's Travels and this adaptation, see Karen Gevirtz, review of Gulliver's Travels, Eighteenth-Century Studies 44, no. 4 (2011): 559-64.

26. Gulliver's Travels, directed by Rob Letterman (Beverly Hills, CA: Twentieth Century Fox Home Entertainment, 2011), DVD.

27. Similarly, the film collapses all islands with a colonial history into one homogenized locale. Although Gulliver goes to Bermuda, his guide has a Jamaican accent and the soundtrack during this part of the film is Reggae, which originated in Jamaica, not Bermuda.

28. Dianne F. Sadoff and John Kucich, "Introduction: Histories of the Present," in Sadoff and Kucich, Victorian Afterlife, ix.

29. Umberto Eco, Travels in Hyperreality, trans. William Weaver (New York: Harcourt Brace Jovanovich, 1986), 3-58; Susan Stewart, On Longing: Narratives of the Miniature, the Gigantic, the Souvenir, the Collection (Baltimore: The Johns Hopkins University Press, 1984), 151-62. Eco considers this behavior particularly American: "The American imagination demands the real thing and, to attain it, must 
fabricate the absolute fake" (8). Eco's allusions to the German Wunderkammer (5, 6) connect this tendency back to the seventeenth- and eighteenth-century cabinets of curiosity popular in Europe and in England, where the British Museum was founded on the collection amassed by Sir Hans Sloane. For a discussion of collecting and miscellanies in England, see for example Barbara M. Benedict, "Collecting Trouble: Sir Hans Sloane's Literary Reputation in Eighteenth-Century Britain," EighteenthCentury Life 36, no. 2 (Spring 2012): 111-42; Stacey Sloboda, "Displaying Materials: Porcelain and Natural History in the Duchess of Portland's Museum," ECS 43, no. 4 (Summer 2010): 455-72.

30. Eco, Hyperreality, 8.

31. It is worth noting that the film retains its unexamined representation of the past in the clothes and architecture at its end, however. While ideology, behavior, and speech have been reformed to suit contemporary ideals, the Lilliputians retain their eighteenth-century wardrobe, including the corsets. Evidently some ways of restricting women are permitted to remain.

32. Favret points out that in Emma Thompson's adaptation of Sense and Sensibility, the "avid consumerism promoted by the film" is supported by a rejection of reading in favor of viewing (80).

33. In addition to Darcy Silverman's hiring and sleeping with Gulliver, Princess Mary elevates Horatio by marrying him. In both cases, women in authority are contained at the end of the film within a romantic narrative, not unlike the conversion of Jane Austen into a romantic heroine discussed earlier in the paper. Women who use their power for other purposes, however, are not just frightening but, in the parlance of this Gulliver's Travels, downright dangerous, as in the case of the temperamental, violent Glumdalclitch, who seems to have been constructed out of a multifaceted castration anxiety.

34. Stephen Gallagher et al, Crusoe, directed by Duane Clark (Universal City, CA: Universal Studios Home Entertainment, 2009), DVD. All further references to episodes will be to this DVD.

35. See for example Hans Turley, Rum, Sodomy, and the Lash: Piracy, Sexuality, and Masculine Identity (New York: NYU Press, 1999); Srinivas Aravamudan, Tropicopolitans: Colonialism and Agency, 1688-1804 (Durham: Duke University Press, 1999); DeeAnn DeLuna, "Robinson Crusoe, Virginal Hero of the Commercial North," Eighteenth-Century Life 28, no. 1 (2004): 69-91; George E. Haggerty, "Thank God It's Friday: The Construction of Masculinity in Robinson Crusoe," in Novak and Fisher, Approaches to Teaching Defoe's Robinson Crusoe, 84-85.

36. DeLuna, "Robinson Crusoe," 70.

37. Laura Brown, The Ends of Empire: Women and Ideology in Early EighteenthCentury English Literature (Ithaca: Cornell University Press, 1993), 14-19, 113.

38. Robert Mayer, "Robinson Crusoe in Hollywood," in Novak and Fischer, Approaches, 169-74.

39. For a thoughtful reading of the significance of Wilson in terms of race, see Mayer, "Robinson Crusoe in Hollywood," 172-73.

40. "Theoretically fraternal" because the amount of effort that the series puts into affirming Robinson's heterosexuality suggests the degree to which the relationship, 
particularly when it involves keeping house even if the men have separate bedrooms, has queer undertones.

41. Pollard, Approaches, 163-64; Haggerty, "Thank God It's Friday," in Novak and Fischer, Approaches, 79-81; Roxann Wheeler, "Robinson Crusoe and Early-Eighteenth-Century Racial Ideology," in Novak and Fisher, Approaches, 88-95; Abby A. Johnson, "Old Bones Uncovered: A Reconsideration of Robinson Crusoe," CLA Journal 17 (1973): 71-78. Wheeler points out that "reading for racial multiplicity" in texts like Robinson Crusoe reveals how race was an "emergent, rather than stable concept in the eighteenth century." Roxann Wheeler, “"My Savage,' "My Man': Racial Multiplicity in Defoe's Robinson Crusoe," ELH 62, no. 4 (Winter 1995): 821, http://www.jstor.org/stable/30030104.

42. See for example Gwen Ifill, The Breakthrough: Politics and Race in the Age of Obama (New York: Doubleday, 2009); Roy L. Brooks, Racial Justice in the Age of Obama (Princeton: Princeton University Press, 2009). Brooks uses the term "post-civil rights," arguing that "The Age of Obama is not, in my view, postracial. It is racial," but that the civil rights movement has ended (xiii).

43. Unknown, "Weapons, Gadgets, and Traps."

44. Unknown, "Weapons, Gadgets, and Traps."

45. Robinson and Friday also have a highly ecologically responsible approach to technology. In the final episode, for example, when Robinson's enemy Josiah Blackthorn says admiringly, "You've tamed the wilderness," Robinson replies, "Hardly. I've adapted to it." Similarly, in "The Hunting Party," Friday delivers a monologue to their dog about the necessity for living in harmony with nature.

46. Raymond Malewitz, "Regeneration through Misuses: Rugged Consumerism in Contemporary American Culture," PMLA 127, no. 3 (2012): 527. For some reason Malewitz views "rugged consumers" as more than one archetype, but of course the "rugged consumer" can only be one archetype, although it may appear in many forms, just as the "hero" can only be one archetype, even if it takes many forms.

47. Malewitz, "Regeneration," 532, 539.

48. A. O. Scott, "A Gut Visible All the Way from the Eighteenth Century," The New York Times, December 24, 2010 C: 6 (late edition), http://www.lexisnexis.com. ezproxy.shu.edu/hottopics/lnacademic/?shr=t\&sfi=AC00NBGenSrch\&csi=6742.

49. Hutcheon, Adaptation, 8; original emphasis.

50. Favret, Afterlives, 66.

51. Eco, Hyperreality, 68, 68-72.

52. Eco, Hyperreality, 72. 